\title{
Episodes of extreme rainwater pollution and its relationship with synoptic situation (Wielkopolski National Park, Poland)
}

\author{
Leszek Kolendowicz • Ewa Bednorz • Barbara Walna • \\ Iwona Kurzyca
}

Received: 10 June 2011 /Accepted: 16 November 2011 /

Published online: 7 December 2011

(C) The Author(s) 2011. This article is published with open access at Springerlink.com

\begin{abstract}
Synoptic conditions of extreme rainwater pollution episodes, evidenced by maximum values of parameters measured in the protected area of Wielkopolski National Park (western-central Poland), were analysed in this study. Precipitation samples were tested for the following parameters: $\mathrm{pH}$, electrical conductivity and the concentration of the following elements: $\mathrm{F}^{-}, \mathrm{Cl}^{-}, \mathrm{NO}_{2}{ }^{-}, \mathrm{NO}_{3}{ }^{-}, \mathrm{PO}_{4}{ }^{3-}, \mathrm{SO}_{4}{ }^{2-}$ and $\mathrm{Na}^{+}, \mathrm{NH}_{4}{ }^{+}, \mathrm{K}^{+}, \mathrm{Mg}^{2+}, \mathrm{Ca}^{2+}$. It was assumed, that in winter, western advection of Atlantic air masses was the most frequent aerosol and pollution transport scenario for the investigated area. In summer the most heavily pollution occur at the intensified meridional flow over the central Europe, indicating advection of cooler air from northern Europe and the North Sea. In most of cases, the weather conditions causing extreme concentration of examined pollutants, were determined by the movement of weather fronts over considerable parts of Poland and by precipitation caused by those fronts.
\end{abstract}

Keywords Atmospheric pollution · Atmospheric circulation · Synoptic situations · Back trajectories

\section{Introduction}

Wielkopolski National Park (western-central Poland) is a particularly protected area. Its key landscape assets, including numerous lakes, woodlands, strict reserves offering refuge to

L. Kolendowicz $\cdot$ E. Bednorz

Department of Climatology, Institute of Physical Geography and Environmental Planning, Faculty of Geographical and Geological Sciences, Adam Mickiewicz University,

Dziegielowa 27 Str., 60-680 Poznan, Poland

B. Walna

Jeziory Ecological Station of Adam Mickiewicz University, 62-050 Mosina P.O. Box 40, Poland

I. Kurzyca $(\bowtie)$

Department of Water and Soil Analysis, Faculty of Chemistry, Adam Mickiewicz University,

Drzymaly 24 Str., 60-613 Poznan, Poland

e-mail: ikurzyca@amu.edu.pl 
many wildlife species, require one to determine the level and the causes of negative changes taking place in the Park's ecosystems. One particular threat to the Park's nature is air pollution caused by the vicinity of Poznań, a city of 700 thousand inhabitants, as well as a number of neighbouring towns with populations just under 10 thousand (Raszka 1997; Michałowski et al. 2003; Kowalski 2004). Another cause is the heavy traffic on a road cutting through the middle of the Park (Górski and Przybyłek 2003). Gaseous pollutants come also from more distant sources. In the region of Wielkopolska (area about 30 thousand of square kilometres), the emission of air pollutants from plants generating substantial pollution in 2008 was as follows: $\mathrm{NO}_{\mathrm{x}}-27.3$ thousand tons, $\mathrm{SO}_{2}-110.6$ thousand tons and $\mathrm{CO}_{2}-18104.5$ thousand tons. The emission of particulates amounted to 6.6 thousand tons (Environment Protection 2009).

Composition of atmospheric precipitation depends not only on the location, type and intensity of the pollution source, but also on the chemical processes taking place in the atmosphere, as well as on the transport of pollutants with air masses (Avila and Alarcon 1999). The relationship between the emission of pollutants, their atmospheric transport has been investigated to a fair degree of detail (e.g.: Rodhe et al. 1995; Matson et al. 2002). It has been found that both concentration of atmospheric pollutants as well as their distribution closely depend on time and space related key meteorological elements, such as air humidity and temperature, atmospheric pressure or wind speed, as well as the thermodynamic stability of air masses (Scheringer 2009; Gasic et al. 2010). The most important factors seem to be those related to the wind structure (speed and direction) and to various states of thermodynamic stability of the atmosphere, which determine the vertical movement of air. Other important factors include steam condensate altitude, form of precipitation (rain, snow), precipitation intensity and duration (Tamulewicz et al. 2004).

Due to the close relationship between precipitation and meteorological elements, analyses of atmospheric circulation in the period of precipitation are carried out in order to identify the underlying cause of differences in substance concentrations in various samples of precipitation (Dayan and Lamb 2007). In Poland, atmospheric circulation is determined by the distribution of pressure centers over the Atlantic Ocean and Eurasia. As a result of their movements, genetically diverse masses of air reach the territory of Poland (Twarowski et al. 2001; Kolendowicz et al. 2010). It is estimated that air-borne pollutants account for a considerable share of the global circulation (Holloway et al. 2003). In 2003, the balance of transborder movements of sulphur and nitrogen pollutants from Germany to Poland was estimated at 183 thousand tons and 133 thousand tons, respectively (Environment Protection 2005). To assess potential distant sources of pollution, analyses of trajectories of air masses reaching the measurement point are carried out. The so-called back trajectories have been frequently used to identify the origin of pollution, e.g. for Central Europe in the case of high levels of sulphate concentration (Dayan and Lamb 2005), or for north-eastern Spain in determining precipitation chemistry (Avila and Alarcon 1999). The 5-day back air trajectories were also used to evaluate aerosol sources at European mountain sites (Salvador et al. 2010).

The composition of atmospheric precipitation collected at the Jeziory Ecological Station of the Adam Mickiewicz University, located in the centre of the Park, may provide important information about the existing threats. These studies have been conducted since 1991 and confirmed significant pollution of precipitation (Walna and Siepak 1999; Walna et al. 2004, 2007; Walna et al. 2010).

The aim of the study was to analyze the relationship between atmospheric circulation and extreme pollution of atmospheric precipitation, evidenced by maximum values of parameters measured in the protected area of Wielkopolski National Park. 


\section{Study area and methodology}

The tests were carried out in the Jeziory Ecological Station of the Adam Mickiewicz University located within the boundaries of Wielkopolski National Park (N 52 15' $56^{\prime \prime} \mathrm{E} 16^{\circ} 48^{\prime} 6^{\prime \prime}$ ), in the period from 2007 to 2009. In accordance with the guidelines of International Forest Manual (2006), 240 samples were collected, using the $24 \mathrm{~h}$ system. Each sample was tested for the following parameters: precipitation amount (manually - Hellman rain gauge), $\mathrm{pH}$ (CP-315 pH-meter, in compliance with ISO 10523:2008), electrical conductivity (Elmetron conductometer CC-311, in compliance with ISO 7888:1985) and the concentration of the following ions: $\mathrm{F}^{-}, \mathrm{Cl}^{-}, \mathrm{NO}_{2}{ }^{-}, \mathrm{NO}_{3}{ }^{-}$, $\mathrm{PO}_{4}{ }^{3-}, \mathrm{SO}_{4}{ }^{2-}$ and $\mathrm{Na}^{+}, \mathrm{NH}_{4}{ }^{+}, \mathrm{K}^{+}, \mathrm{Mg}^{2+}, \mathrm{Ca}^{2+}$ (Dionex DX 120 ion chromatograph in compliance with ISO 14911:1998 and ISO 21438, parts 1, 2, and 3). Quality Control and Quality Assurance procedures were used both during sampling and during chemical analysis (Kurzyca et al. 2009).

In accordance with the objectives of the research project, cases of extreme values of $\mathrm{pH}$ and conductivity of precipitation were identified. The 90th percentile served as a differentiating criterion. The said method is in keeping inter alia with the approach recommended by the IPCC (IPCC 2001) for determining extreme weather events. A similar criterion was used in the atlas of extreme meteorological phenomena and synoptic situations in Poland (Ustrnul and Czekierda 2009). The next step consisted of determining the frequency of extreme concentrations, $\mathrm{pH}$ values and conductivity. Subsequently, out of the 240 sampling dates 9 days were selected when at least eight of the 13 analyzed pollutants and parameters exceeded the boundary value. It needs to be mentioned that the maximum number of parameters simultaneously exceeding the extreme values was never greater than 11 , even on the days characterized by the most polluted precipitation. In 2007, 2 days met the above criterion: April 10 and June 1. In 2008, there were six such days: February 18, February 20, February 22, May 16, June 13 and November 27.

Following the identification of dates with extreme pollution parameters, an analysis of synoptic situation was carried out for such dates and for preceding days. To that end, synoptic maps as of 00.00 UTC published by the Institute for Meteorology and Water Management in the Daily Meteorological Bulletins (2007, 2008) were used. To refine the pressure field analysis, maps presenting pressure anomalies for the selected 7 days with highly polluted precipitation were drawn. Anomalies were computed as differences between the values of sea level pressure (SLP) on the particular day and means for years 2007-2008, using data from the National Centers for Environmental Prediction (NCEP) - National Center for Atmospheric Research (NCAR) reanalysis (Kalnay et al. 1996). The interpretation of the anomaly map is similar to the traditional weather maps, with clockwise (anticyclonic) flow around the positive centres and counterclockwise (cyclonic) flow around the negative centres (Birkeland and Mock 1996). Furthermore, 3 to 5 day back trajectories were analyzed for each of the days with extreme air pollution, using the NOAA HYSPLIT model (http://ready.arl.noaa.gov/HYSPLIT.php). The model analyzed air masses movement for three altitudes above sea level: $500 \mathrm{~m}$ (corresponding to the central part of the mixing layer), $3,000 \mathrm{~m}$ (corresponding to the mean altitude with isobaric surface of $700 \mathrm{hPa}$ ) and $8,000 \mathrm{~m}$ (corresponding to the altitude on which stream current is found). An analysis of air trajectory at the three altitudes provided significant input to the information obtained from synoptic maps and made it possible to identify probable sources of pollution. 


\section{Results}

The physical and chemical characteristics of atmospheric precipitation are presented in Table 1 . Over the analyzed period of 3 years, precipitation was observed to have high electric conductivity, up to a maximum of $169 \mu \mathrm{S} \cdot \mathrm{cm}^{-1}$ (2008), which denotes heavy pollution. The $\mathrm{pH}$ of rainwater in the Wielkopolski National Park indicates its high acidity. On a few occasions, minimum $\mathrm{pH}$ values of approximately 3.5 were recorded, and the weighted average $\mathrm{pH}$ value calculated on the basis of hydrogen ion concentrations did not exceed 4.5. The recorded extreme concentrations of acid-forming compounds are many times higher than the mean values, thus confirming inflows of highly polluted air masses.

The results for the Jeziory station were compared with those of six lowland backgroundstudying stations belonging to the European EMEP Network (Co-operative Programme for Monitoring and Evaluation of the Long-range Transmission of Air Pollutants in Europe): from Germany-DE002 and DE007, Poland-PL002 and PL005, Belarus-BY004, and the Czech Republic - CZ003 (EMEP/MSC-W, 2007-2009). The mean annual pH values for the Wielkopolski National Park are the lowest, which indicates substantial immission of acid-forming compounds from local, regional, and transborder sources. The precipitation studied by the authors showed the annual mean concentration of sulphates varying from $2.13 \mathrm{mg} \mathrm{l}^{-1}$ (2007) to $2.59 \mathrm{mg} \mathrm{l}^{-1}$ (2009), while the mean figure at the lowland backgroundstudying stations in Poland amounted from $1.17 \mathrm{mg} \mathrm{l}^{-1}$ (PL005, 2009) to $2.34 \mathrm{mg} \mathrm{l}^{-1}$ (PL002, 2007). A comparison of the sulphate concentration values in the neighbouring EMEP member countries showed them to be lower than those for precipitation under study (Fig. 1), with the exception of the station in Belarus (BY004), which recorded higher concentration. The annual mean nitrates concentration at Jeziory precipitation varied from $1.75 \mathrm{mg} \mathrm{l}^{-1}$ (2007) to $2.37 \mathrm{mg} \mathrm{l}^{-1}$ (2009), and were similar to the mean figures obtained at the chosen EMEP stations (Fig. 1).

To identify the emission sources, a correlation between the acidifying species was made. The results obtained allow indicating two main anthropogenic sources: industrial and agricultural. A good correlation $(r>0.66$ for $p<0.05)$ between the species $\left(\mathrm{SO}_{4}{ }^{2-} / \mathrm{NO}_{3}{ }^{-}, \mathrm{SO}_{4}{ }^{2-} / \mathrm{Cl}^{-}\right)$shows the impact of industrial/combustion emitters located in the vicinity and far from the study area. In particular, the fertilizer plant located at a distance of $10 \mathrm{~km}$ may cause the high correlation between $\mathrm{F}^{-} / \mathrm{SO}_{4}{ }^{2-}(r=0.76$ for $p<0.05)$. A detail description of the fluoride level in precipitation has been presented in a previous paper (Walna et al. 2007). Additionally, the elevated nitrate concentrations in rainwater in 2009 can be due to a nearby motorway (a distance of $5 \mathrm{~km}$ ) and local roads $(200 \mathrm{~m})$. The correlation between $\mathrm{K}^{+} / \mathrm{Mg}^{2+} / \mathrm{Ca}^{2+}$ can be explained as an influence of soil and ash particles. A chemometric analysis of pollution sources in western Poland can be found in

Table 1 Basic statistical parameters of atmospheric precipitation chemistry at the Jeziory Ecological Station of the Adam Mickiewicz University (2007-2009)

\begin{tabular}{llllllllllllllll}
\hline$n=240$ & $\mathrm{pH}$ & $\mathrm{K}$ & $\mathrm{Na}^{+}$ & $\mathrm{NH}_{4}^{+}$ & $\mathrm{K}^{+}$ & $\mathrm{Mg}^{2+}$ & $\mathrm{Ca}^{2+}$ & $\mathrm{F}^{-}$ & $\mathrm{Cl}^{-}$ & $\mathrm{NO}_{2}^{-}$ & $\mathrm{NO}_{3}^{-}$ & $\mathrm{PO}_{4}{ }^{3-}$ & $\mathrm{SO}_{4}{ }^{2-}$ \\
& - & $\mu \mathrm{S} \cdot \mathrm{cm}^{-1}$ & $\mathrm{mg} \cdot l^{-1}$ & & & & & & & & & & & & \\
\hline min & 3.45 & 7.6 & 0.05 & 0.11 & 0.03 & $<0.01$ & 0.03 & $<0.003$ & 0.03 & $<0.01$ & $<0.01$ & $<0.02$ & 0.35 \\
max & 7.40 & 169 & 5.54 & 14.1 & 10.7 & 3.46 & 11.8 & 0.280 & 12.5 & 0.43 & 13.5 & 9.04 & 24.0 \\
weight. avr. & 4.44 & 26.5 & 0.33 & 1.91 & 0.49 & 0.23 & 1.18 & 0.027 & 0.73 & 0.02 & 2.11 & 0.16 & 2.33 \\
median & 4.52 & 32.0 & 0.35 & 2.11 & 0.29 & 0.17 & 0.97 & 0.030 & 0.83 & 0.02 & 2.38 & 0.07 & 2.68
\end{tabular}

$\mathrm{K}$ - electrical conductivity 


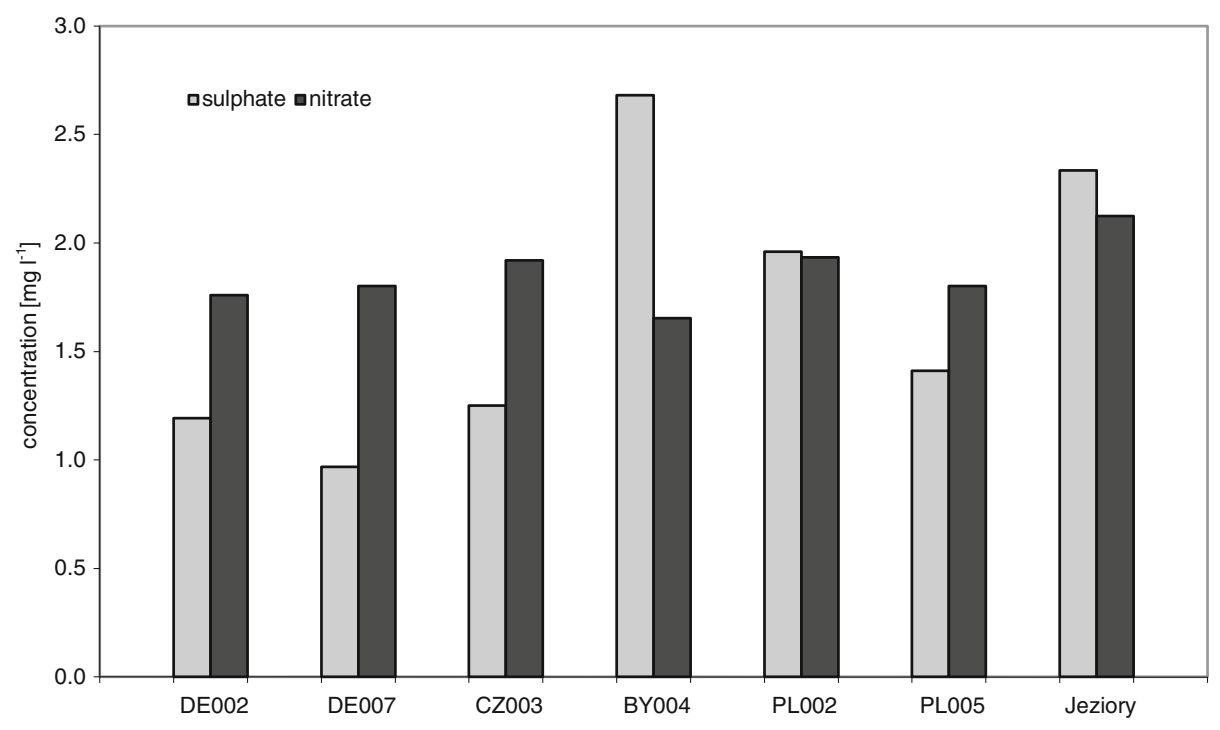

Fig. 1 Main acid-forming ions from some European EMEP stations and the Jeziory stations in 2007-2009 (weighted average concentration)

our previous paper (Astel et al. 2008). The intensive agriculture of the region could account for the high concentration of ammonium ions correlated with nitrates $(r=0.70$ for $p<0.05)$. The highest correlation coefficient $(0.86)$ for $\mathrm{Na}^{+} / \mathrm{Cl}^{-}$indicates the influence of polar-maritime air masses flowing in from the Baltic and North Seas-a nonanthropogenic source of pollution. Correspondingly, the precipitation caused by western (W) and northwestern (NW) directions of air flow characterize with the highest concentration of $\mathrm{Na}^{+}$and $\mathrm{Cl}^{-}$which confirm the natural source of pollutants transported by polar maritime air masses (Table 2)

Correlation coefficients between the chemical composition of precipitation and the air flow direction were not statistically significant. However, it was found, that the western and

Table 2 Chemical composition of rainwater according to air-flow directions ( $\mathrm{O}$ - no prevailing direction); Wielkopolski National Park; years 2007-2009. Values exceeding the third quartile marked in bold

\begin{tabular}{|c|c|c|c|c|c|c|c|c|c|c|c|}
\hline Air-flow directions & $\begin{array}{l}\mathrm{pH} \\
-\end{array}$ & $\begin{array}{l}\mathrm{K} \\
\mu \mathrm{S} \cdot \mathrm{cm}^{-}\end{array}$ & $\mathrm{Na}^{+}$ & $\mathrm{NH}_{4}^{+}$ & $\mathrm{K}^{+}$ & $\mathrm{Mg}^{2+}$ & $\begin{array}{l}\mathrm{Ca}^{2+} \\
\mathrm{mg} \cdot 1^{-1}\end{array}$ & $\mathrm{~F}^{-}$ & $\mathrm{Cl}^{-}$ & $\mathrm{NO}_{3}^{-}$ & $\mathrm{SO}_{4}{ }^{2-}$ \\
\hline $\mathrm{N}$ & 4.59 & 37.64 & 0.61 & 2.84 & 0.58 & 0.29 & 1.24 & 0.034 & 1.43 & 2.85 & 3.13 \\
\hline $\mathrm{NE}$ & 4.69 & 38.26 & 0.61 & 2.34 & 0.54 & 0.38 & 1.62 & 0.039 & 1.28 & 2.36 & 3.22 \\
\hline $\mathrm{E}$ & 4.74 & 36.46 & 0.36 & 2.78 & 0.92 & 0.41 & 1.79 & 0.035 & 0.96 & 2.74 & 3.83 \\
\hline SE & 4.20 & 48.09 & 0.38 & 2.80 & 0.28 & 0.20 & 1.18 & 0.037 & 1.02 & 3.20 & 4.35 \\
\hline S & 4.42 & 45.58 & 0.35 & 2.74 & 0.57 & 0.30 & 1.61 & 0.037 & 0.79 & 2.72 & 3.78 \\
\hline SW & 4.59 & 37.52 & 0.35 & 2.72 & 0.37 & 0.18 & 1.33 & 0.033 & 0.91 & 2.56 & 3.54 \\
\hline W & 4.72 & 46.39 & 0.63 & 3.85 & 1.22 & 0.46 & 2.45 & 0.054 & 1.50 & 4.02 & 5.39 \\
\hline NW & 4.73 & 39.81 & 0.79 & 3.40 & 0.84 & 0.36 & 1.34 & 0.039 & 1.58 & 2.94 & 3.62 \\
\hline $\mathrm{O}$ & 4.19 & 43.38 & 1.05 & 2.23 & 0.66 & 0.54 & 1.12 & 0.045 & 2.57 & 3.19 & 3.50 \\
\hline
\end{tabular}

K - electrical conductivity 
northwestern directions bring in general the most polluted precipitation (Table 2). Only selected pollutants, like nitrate and sulphate concentration, reach the highest level at the presence of high pressure systems over Poland, which characterize with the weak south/southeast circulation or no prevailing direction. Such synoptic situation is favorable for pollution from local emitters, including traffic at nearby roads and local domestic emission.

Selected precipitation episodes (Table 3), described below from a synoptic perspective, occurred in winter and in late spring. They were characteristic for small amounts of precipitation ( $0.8 \mathrm{~mm}$ on average) and varying $\mathrm{pH}$ value (both acidic and neutral). It seems important that their composition is indicative of high concentrations of sulphate, nitrate, chloride and fluoride ions, as well as calcium ions (ammonium ions in particular). Most of the selected cases characterize with the western or north western inflow of air masses, sometimes with south western component in the upper troposphere. These air flow directions bring the most polluted precipitation, according to data in Table 2.

An analysis of synoptic situations for extreme precipitation episodes is presented below.

\subsection{Precipitation on April 10, 2007}

On April 8, 2007 cloud coverage over Poland was significant, with periodically occurring rain, snow or sleet. The maximum air temperature ranged from $6^{\circ} \mathrm{C}$ in the eastern part of the country to $13^{\circ} \mathrm{C}$ in south west. Wind was moderate to fresh, gusty, NW and W. Poland was under the influence of a high pressure area formed over the British Isles and a low pressure system with weather fronts, whose central point was located over the southern part of the Baltic Sea. On April 9, 2007 the intensity of atmospheric precipitation related to the movement of a warm weather front over Poland increased. Temperature grew slightly (by approximately $1^{\circ} \mathrm{C}$ ). Wind was moderate to fresh, coming in gusts from the western sector. Until April 10, 2007 the warm weather front moved beyond the eastern border of Poland. Rainy weather persisted, and so did moderate and fresh western winds (Fig. 2).

The pressure anomaly map shows positive deviations over south western Europe and the southern Atlantic, with the central point located west of the British Isles. Negative deviations can be seen over the northern Atlantic and Scandinavia, with a local centre over the southern part of the Baltic Sea and northern Poland. Such a distribution of pressure

Table 3 Episodes of extreme rainwater pollution, dates of occurrence and its chemical composition

\begin{tabular}{|c|c|c|c|c|c|c|c|c|c|c|c|c|}
\hline Precipitation event & $\begin{array}{l}\text { Amount } \\
\mathrm{mm}\end{array}$ & $\begin{array}{l}\mathrm{pH} \\
-\end{array}$ & $\begin{array}{l}\mathrm{K} \\
\mu \mathrm{S} \cdot \mathrm{cr}\end{array}$ & $\begin{array}{l}\mathrm{Na}^{+} \\
\mathrm{m}^{-1}\end{array}$ & $\mathrm{NH}_{4}^{+}$ & $\mathrm{K}^{+}$ & $\mathrm{Mg}^{2+}$ & $\begin{array}{l}\mathrm{Ca}^{2+} \\
\mathrm{mg} \cdot 1^{-1}\end{array}$ & $\mathrm{~F}^{-}$ & $\mathrm{Cl}^{-}$ & $\mathrm{NO}_{3}^{-}$ & $\mathrm{SO}_{4}^{-}$ \\
\hline 10.04 .2007 & 1.0 & 5.06 & 137 & 1.49 & 11.1 & 0.68 & 0.12 & 4.75 & 0.157 & 5.15 & 10.8 & 19.3 \\
\hline 1.06 .2007 & 0.6 & 6.32 & 100 & 0.27 & 7.03 & 2.17 & 0.07 & 2.82 & 0.041 & 2.02 & 7.90 & 13.6 \\
\hline 18.02 .2008 & 0.3 & 4.27 & 139 & 2.86 & 12.7 & 1.84 & 0.55 & 2.11 & 0.260 & 9.48 & 11.3 & 18.9 \\
\hline 20.02.2008 & 0.2 & 4.02 & 150 & 2.16 & 11.5 & 3.34 & 0.52 & 2.91 & 0.280 & 7.27 & 13.5 & 23.5 \\
\hline 22.02 .2008 & 0.4 & 4.38 & 96 & 1.18 & 10.2 & 0.92 & 0.22 & 1.16 & 0.130 & 3.62 & 9.20 & 13.7 \\
\hline 16.05 .2008 & 1.5 & 6.01 & 87 & 0.69 & 14.1 & 10.74 & 1.25 & 4.12 & 0.110 & 2.54 & 6.26 & 8.5 \\
\hline 13.06 .2008 & 1.5 & 4.50 & 115 & 1.84 & 11.9 & 7.96 & 1.67 & 6.51 & 0.080 & 3.63 & 10.7 & 11.7 \\
\hline
\end{tabular}

K - electrical conductivity 

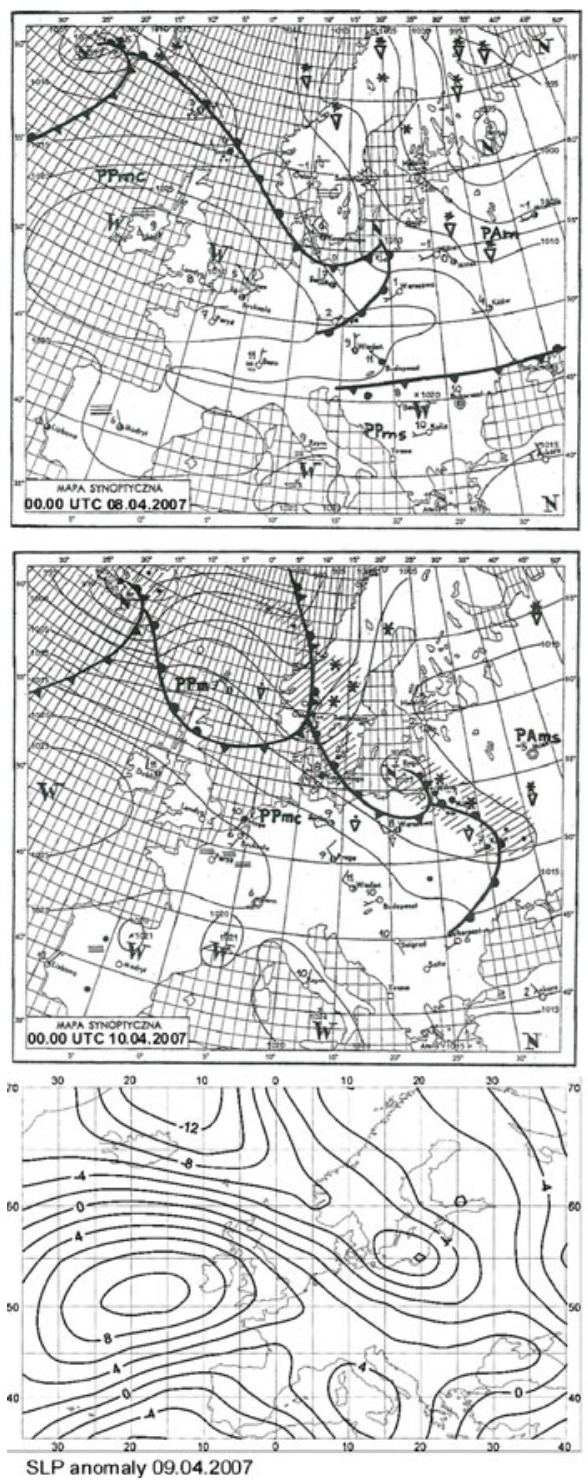

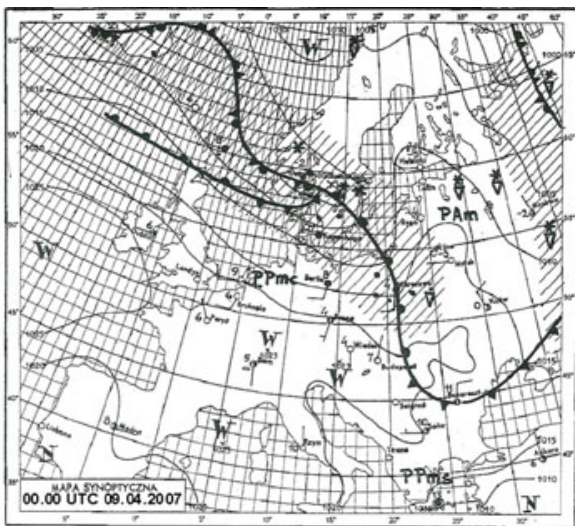

NOAA HYSPLIT MODEL

Backward trajectories ending at 2300 UTC 09 Apr 07 CDC1 Meteorological Data

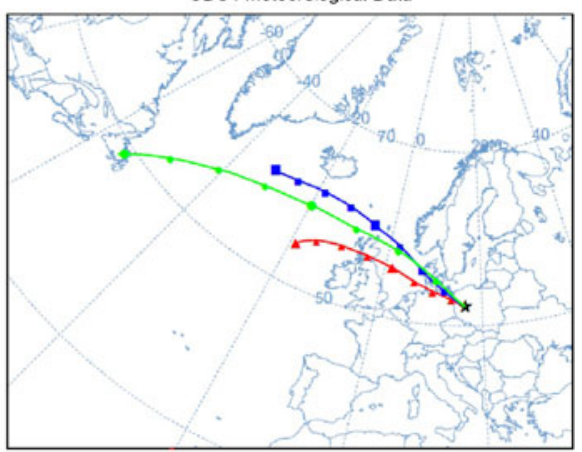

Fig. 2 Synoptic situation for 10.04.2007, including: a sequence of three synoptic charts; 3-day back trajectories at 500 ma.s.1. (marked with triangles), 3,000 ma.s.1. (marked with squares) and 8,000 ma.s.1. (marked with circles) (at bottom right); anomaly map of the sea level pressure (at bottom left)

anomalies is indicative of a large share of the NW component in air mass transport over central Europe.

An analysis of the trajectory of air masses $48 \mathrm{~h}$ prior to the sampling time confirms NW advection at all analyzed altitudes. In the morning of April 9, the incoming air was over the northern part of Germany and crossed the Polish border at around 6 p.m. (Fig. 2). Precipitation-borne pollutants may thus come from sources located in western Poland and/ or in north western Germany. Bearing in mind the time of the year and relatively low air temperatures, the concentration of pollutants may also be affected by local emissions from 
low sources, which is indicated by high presence of sulphur and nitrogen oxides, generated also in coal combustion.

\subsection{Precipitation on June 1, 2007}

In the period from May 30 to June 1 2007, the territory of Poland was under the influence of a small high pressure system centred over Germany and a low pressure centre with a system of fronts located over the southern part of the Baltic Sea (Fig. 3). On May 30, nearly
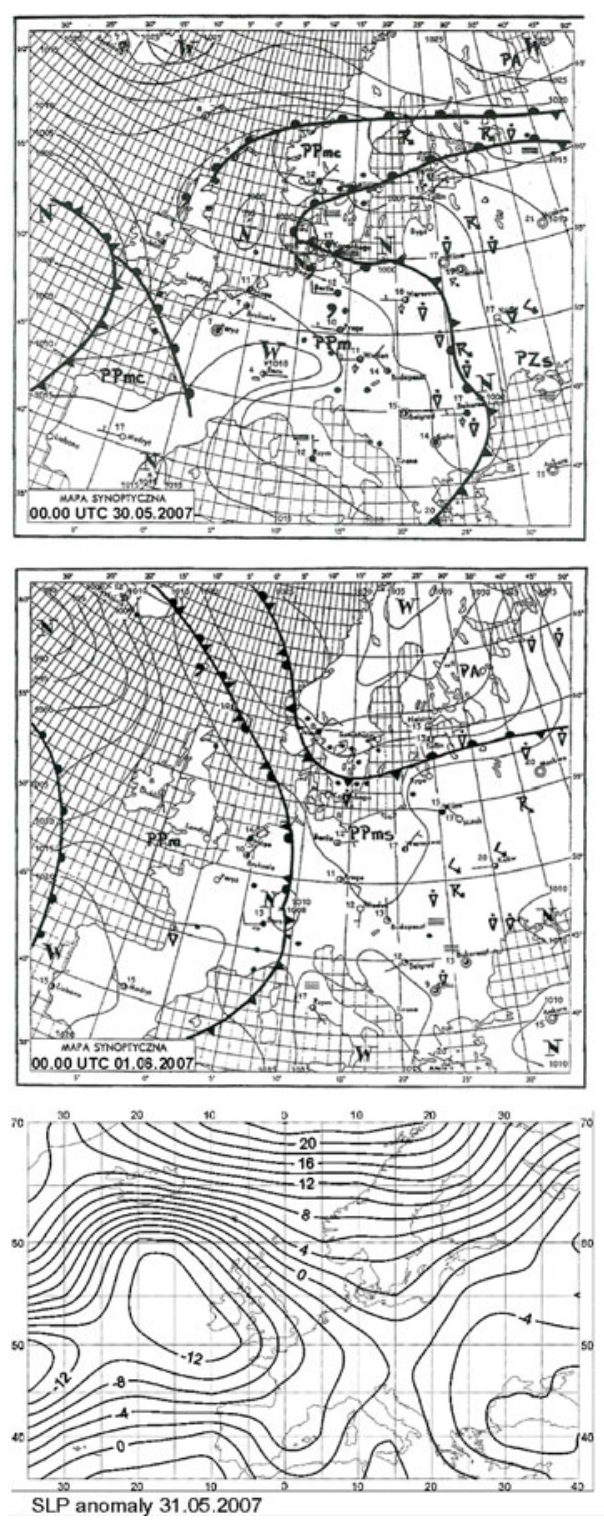

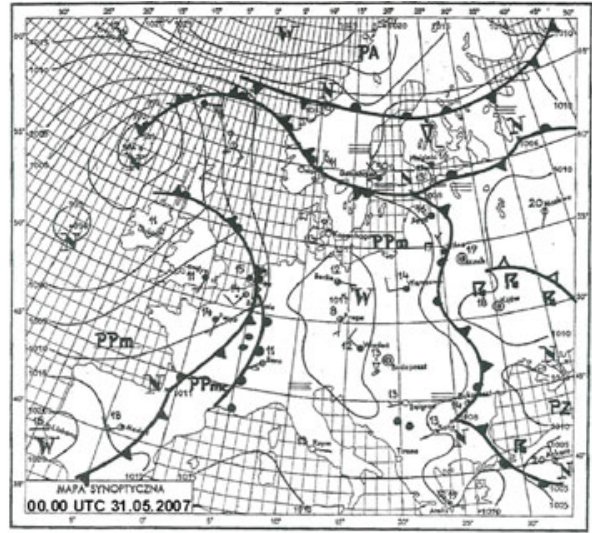

NOAA HYSPLIT MODEL

Backward trajectories ending at 2300 UTC 31 May 07 CDC1 Meteorological Data

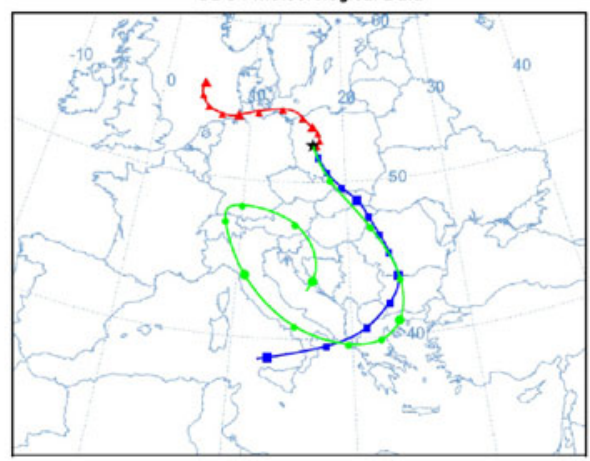

Fig. 3 Synoptic situation for 1.06.2007, description as in Fig. 2 
all of the country saw occasional shower activity. Maximum temperatures ranged from $13^{\circ} \mathrm{C}$ in Jelenia Góra (SW) to $24^{\circ} \mathrm{C}$ in Suwałki (NE). Minimum temperature varied from $7^{\circ} \mathrm{C}$ in the west to $15^{\circ} \mathrm{C}$ in the east of the country. Wind was weak to moderate, $\mathrm{W}$ and N. Over the next 2 days prior to sampling, there were no major weather changes.

The anomaly map of May 31, 2007 shows low pressure over the Atlantic and a significant part of Europe (with its central point of $-12 \mathrm{hPA}$ located west of the British Isles). Increased pressure in the north of the continent is indicative of advection of air masses from the north, which is however confirmed only for the lower layers of the troposphere in back trajectories analysis. In the $48 \mathrm{~h}$ prior to sampling on June 1, 2007, air moved in two directions. At $500 \mathrm{~m}$ above sea level, western advection gradually shifting to northern advection was observed. Above the mixing layer, at both 3000 and $8,000 \mathrm{~m}$ above sea level, air came in from the south (Fig. 3). In the analyzed case, the less distant sources of pollution may be areas located north of the sampling site, while the more distant ones may be those located in southern Poland (Upper Silesia) or beyond the southern border of the country.

\subsection{Precipitation on February 18, 2008}

On the days preceding the sampling date, a high pressure area covering most of Europe weakened gradually, and masses of warm maritime polar air preceded by a warm weather front began to move towards Poland. On February 18 the cloud coverage was thick but clearing. Rain and sleet were observed in the north and west of the country. Maximum temperature ranged from $0^{\circ} \mathrm{C}$ in south east to $6^{\circ} \mathrm{C}$ in north west. Moderate $\mathrm{W}$ and NW wind (Fig. 4). The same air masses movement directions are confirmed by the pressure anomaly map, whereby Poland is located east of a strip of positive deviations, reflecting a high pressure ridge.

An analysis of air advection trajectories prior to sampling shows that at 3,000 and $8,000 \mathrm{~m}$ above sea level air moved in from the north from above the Norwegian Sea and Scandinavia, whereas at $500 \mathrm{~m}$ above sea level it came from north west, from above the North Sea and the north eastern part of Germany (Fig. 4). An analysis of the precipitation sample indicates that the boundary value was exceeded in as many as 9 out of 14 analyzed parameters. The direction of air masses transport indicates north eastern Germany and western Poland as the sources of pollution. One could also point out to local emissions from low sources (households), causing high concentrations of nitrogen and sulphur compounds.

\subsection{Precipitation on February 20, 2008}

Prior to sampling, Poland was dominated by a high pressure system centred over southern Europe. Masses of warm maritime polar air came in from the west, pushing earlier maritime polar air eastwards. Thick clouds were accompanied by rain, sleet and drizzle and by weak to moderate western winds. Maximum temperature varied from $-4^{\circ} \mathrm{C}$ in south east to $8^{\circ} \mathrm{C}$ in north west (Fig. 5).

On Feb. 20, 2008 the distribution of pressure anomalies indicates the presence of a deep low pressure system north of Iceland and a strong baric gradient over the northern part of the Atlantic and Europe. Such a distribution of pressure anomalies clearly indicates western advections. The trajectory presented in Fig. 5 shows southwestern advections in the mixing layer (500 $\mathrm{m}$ above sea level) and western advections at 3,000 and 8,000 $\mathrm{m}$ above sea level. The analyzed precipitation sample is one of the most 

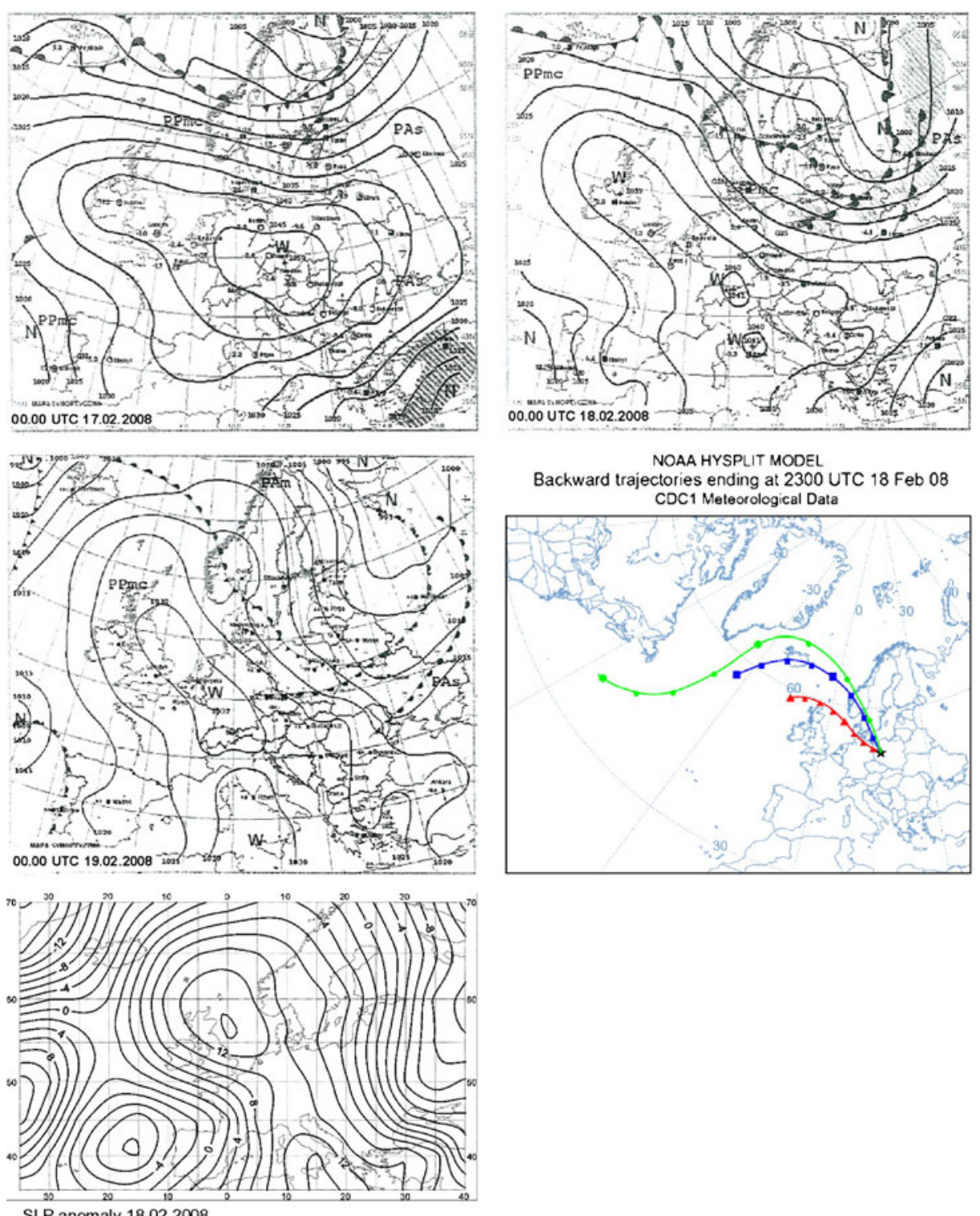

Fig. 4 Synoptic situation for 18.02.2008, description as in Fig. 2

polluted ones, with extreme values recorded in as many as 11 out of 13 parameters. The most probable sources of pollution seem to be the areas located west and south west of the sampling site.

\subsection{Precipitation on February 22, 2008}

Prior to sampling, a relatively fast-paced western advection of maritime polar air was observed over Poland. It was preceded by a warm weather front. Thick but gradually clearing 

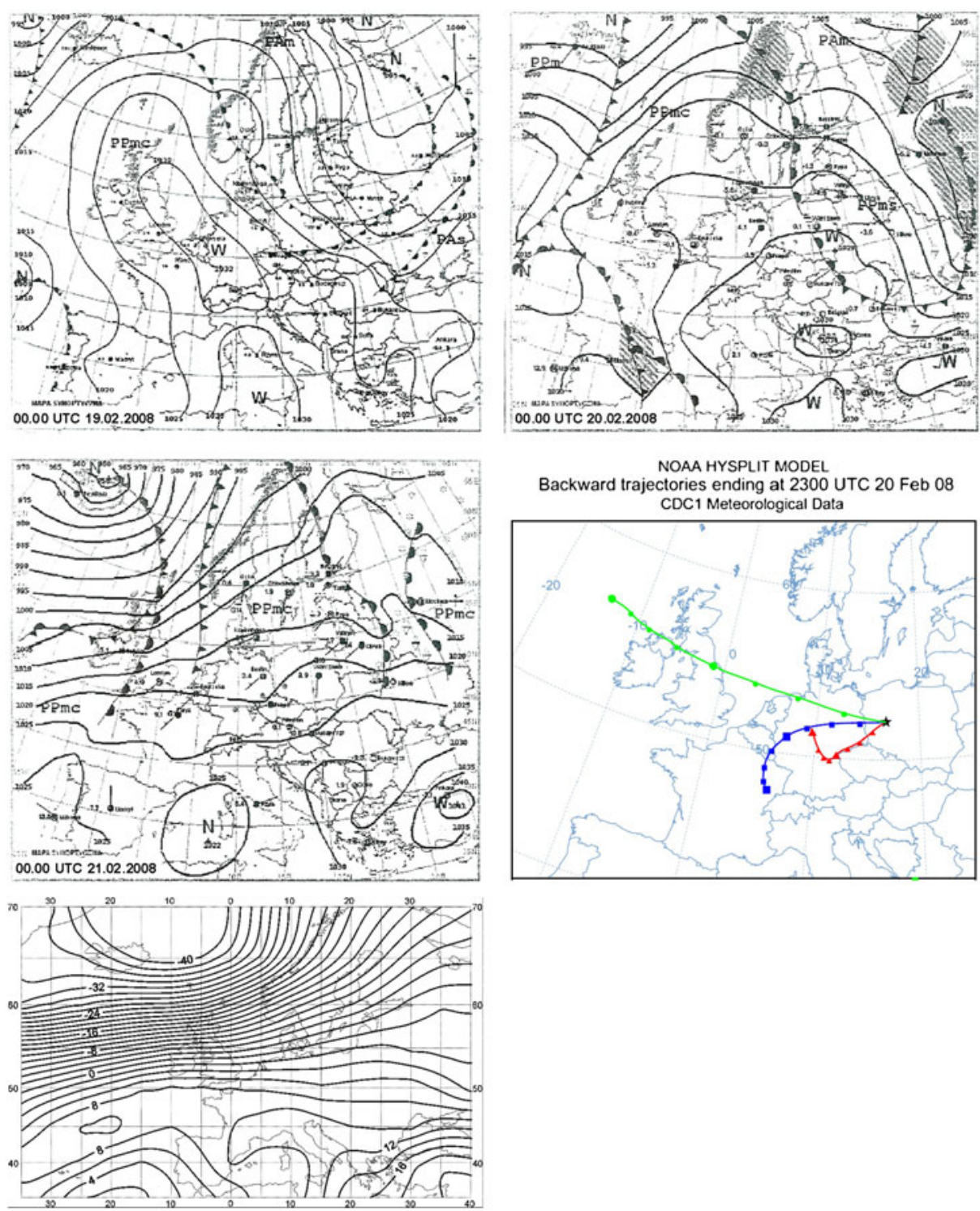

SLP anomaly 20.02 .2008

Fig. 5 Synoptic situation for 20.02.2008, description as in Fig. 2

clouds were accompanied by rain and by moderate SW and W winds. Maximum temperature varied from $3^{\circ} \mathrm{C}$ in south east to $9^{\circ} \mathrm{C}$ in the western part of the country (Fig. 6).

The pressure anomaly map for Feb. 22, 2008 shows positive deviations in southern Europe and over the Mediterranean Sea, while up north air pressure is well below average. The isoline indicates a considerable NW component in air masses trajectory. An analysis of the trajectory of air mass transport shows that the mixing layer is dominated by the western direction, whereas the upper layers are dominated by NW. The most probable origins of pollutions are located in western Poland and north eastern part of Germany (Fig. 6). 

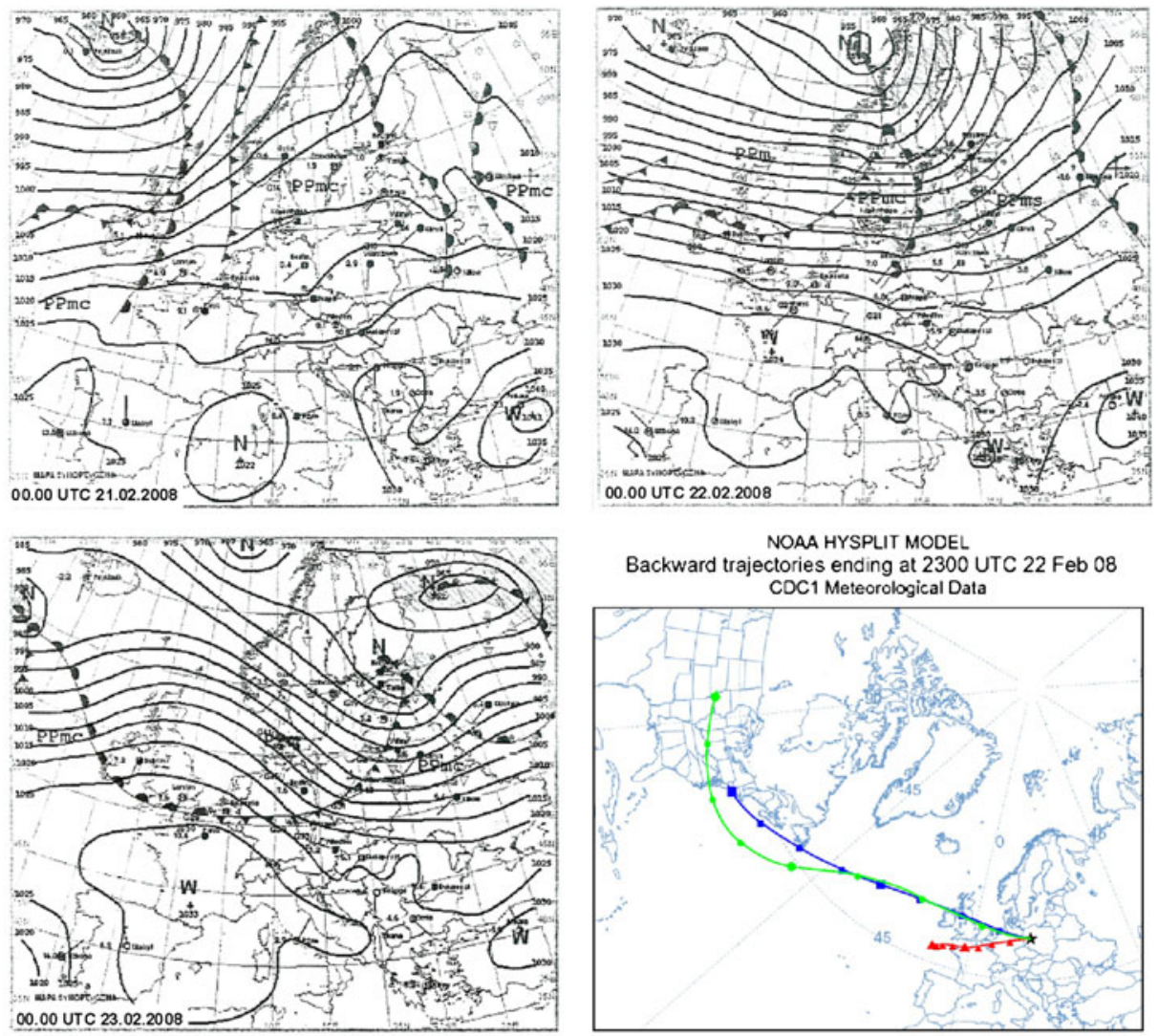

NOAA HYSPLIT MODEL

Backward trajectories ending at 2300 UTC 22 Feb 08 CDC1 Meteorological Data
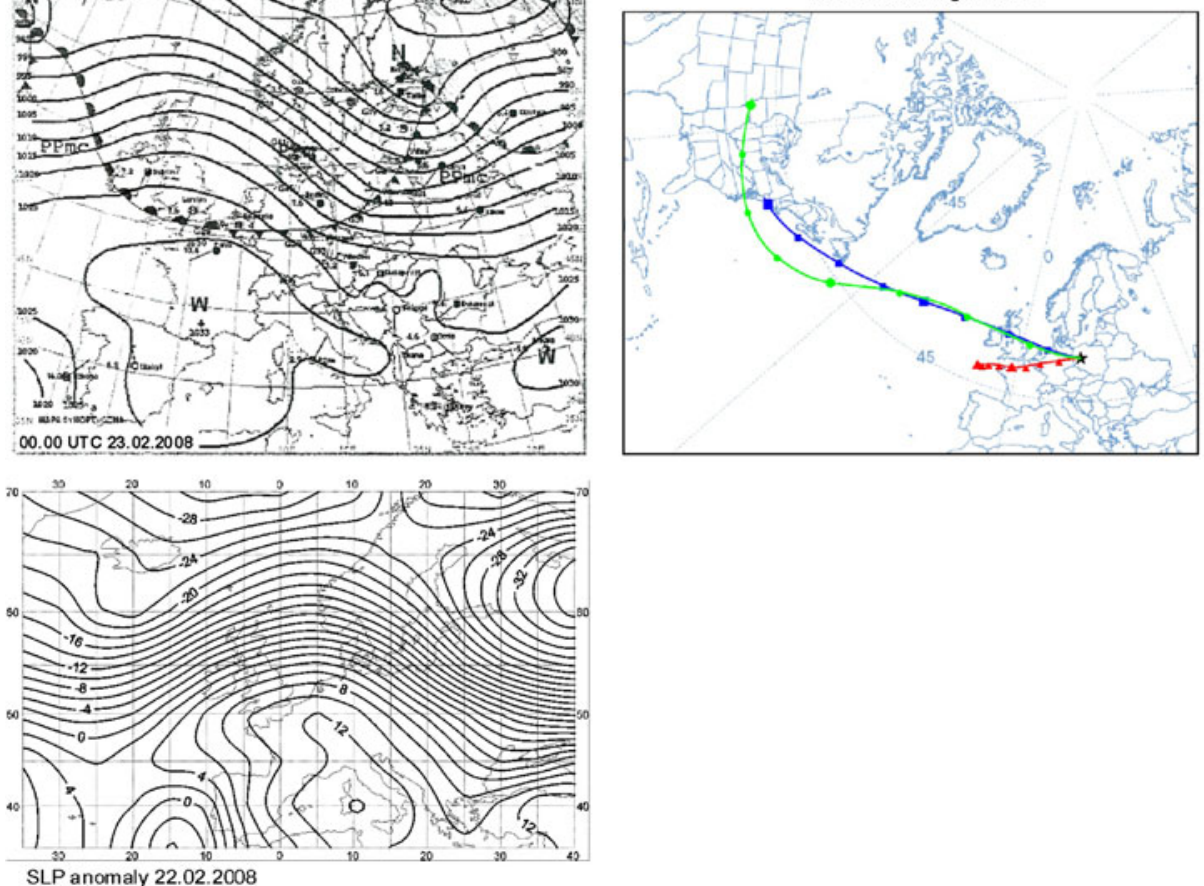

Fig. 6 Synoptic situation for 22.02.2008, description as in Fig. 2

\subsection{Precipitation on May 16, 2008}

On the days prior to sampling the weather was partly cloudy with the exception of southern and central Poland where clouds were thick and caused mild rain and storms locally. Maximum temperature ranged from $13^{\circ} \mathrm{C}$ in the north to $24^{\circ} \mathrm{C}$ in the $\mathrm{SW}$ part of the country. Winds were weak to moderate, with storms bringing in gusty winds from multiple directions (Fig. 7). While the anomaly map shows an increased share of SW advections, the analysis of trajectories of air masses reaching the sampling site 

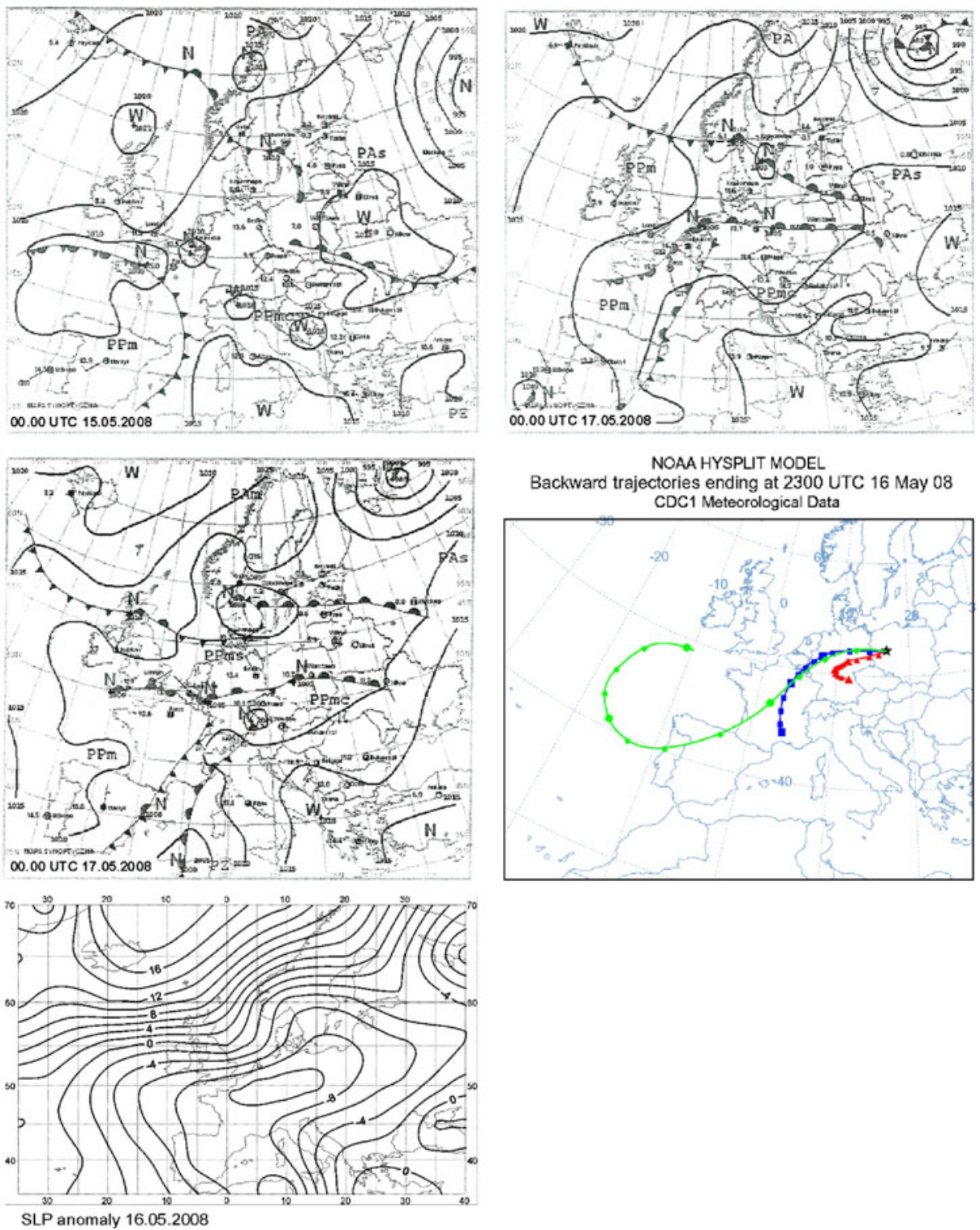

NOAA HYSPLIT MODEL

Backward trajectories ending at 2300 UTC 16 May 08 CDC1 Meteorological Data

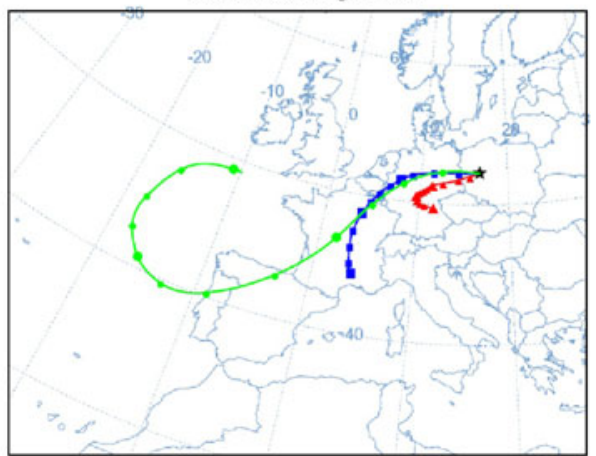

Fig. 7 Synoptic situation for 16.05.2008, description as in Fig. 2

presented in Fig. 7 is indicative of dominant western advections with a rather weak southern component. The probable origins of pollutions are located in western Poland and eastern part of Germany.

\subsection{Precipitation on June 13, 2008}

Prior to sampling the sky was cloudy but clearing, causing mild shower activity. Maximum temperature ranged from $12^{\circ} \mathrm{C}$ in the region of Pomerania (north) to $23^{\circ} \mathrm{C}$ 
in the central and southern part of the country. NW and W winds were weak to moderate (Fig. 8). The air circulated around a low pressure centre located over southern Scandinavia, as seen on the anomaly map. The trajectory of advecting masses of air prior to the sampling time shows that at the altitude of 500 and 3,000 m above sea level the air was coming from the western quadrant, and at 8,000 m-from SW. An analysis of the trajectory shows that the most probable origins of pollutions are located in western Poland and eastern Germany.
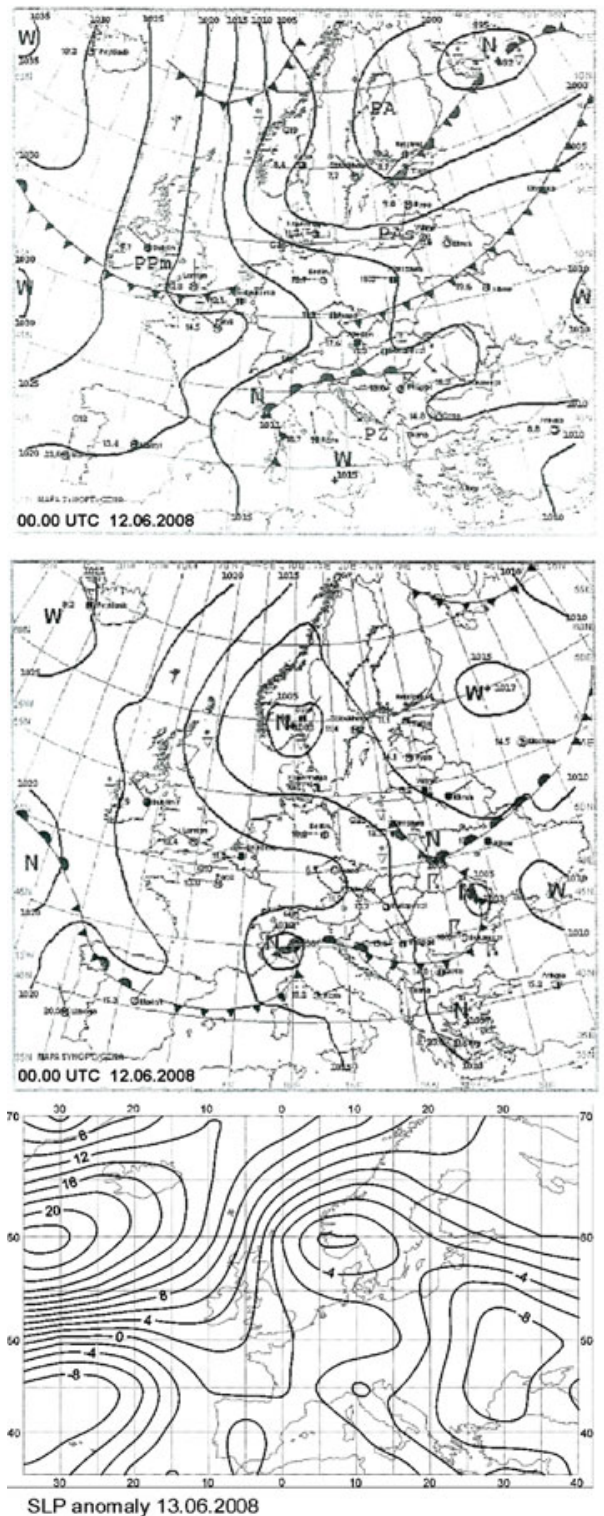

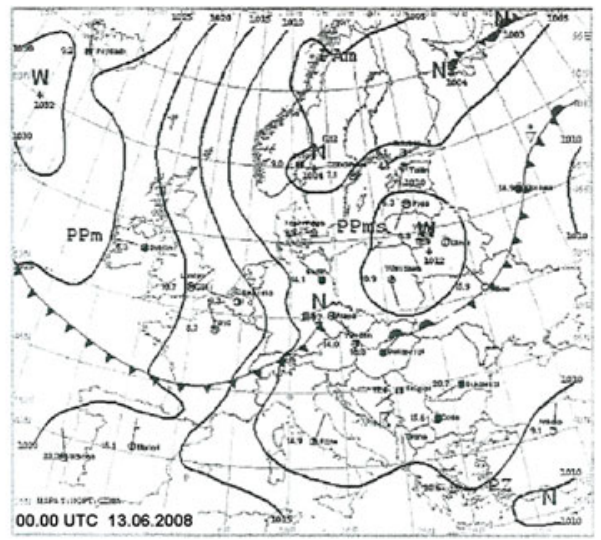

NOAA HYSPLIT MODEL

Backward trajectories ending at 2300 UTC 13 Jun 08 CDC1 Meteorological Data

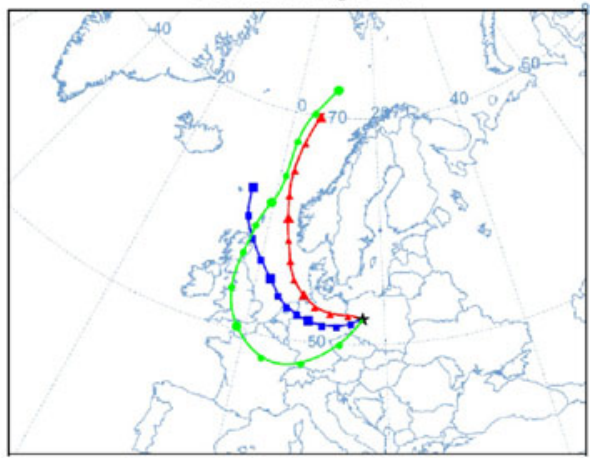

Fig. 8 Synoptic situation for 13.06.2008, description as in Fig. 2 


\section{Discussion and conclusions}

It was recognized in several studies, that neither global nor synoptic-scale atmospheric circulation patterns would ever fully explain all aspects of transport, transformation and deposition of different pollutants in the atmosphere (Dayan and Lamb 2005). Nevertheless, the extreme values approach adopted in this study may confirm some relationships between the synoptic situations and high concentration of pollutants concentration in wet deposition.

An analysis of synoptic situations preceding the days with extreme concentrations of pollution in atmospheric precipitation coupled with an analysis of the trajectories of advection over the air sampling site area allows one to draw the following conclusions:

- In six out of seven cases analyzed above, weather conditions were determined by the movement of weather fronts over considerable parts of Poland and by precipitation caused by those fronts. The only exception was June 1, when atmospheric precipitation occurred within a homogenous mass of persistent maritime polar air. Similar results were obtained in model analysis of the impact of weather events at mid-latitudes on the atmospheric transport of chemical pollutants (Gasic et al. 2010). The atmospheric transport potential is increased during a front event as a result of efficient tropospheric mixing conditions and high wind speed conditions in the upper troposphere.

- In all the analyzed cases air advection over the sampling site in the mixing layer (at an altitude of $500 \mathrm{~m}$ above sea level) originated in the western quadrant, mostly in winter and spring. Western advection was the most common (4 cases). In the three remaining cases the air came from the North and the West. At higher altitudes, in all but one case (6 out 7) advection directions largely corresponded to those in the mixing layer. In general, the western and northwestern directions bring over the area of the study the most polluted precipitation. Only prior to sampling on May 31 the air in the free atmosphere came from the southern sector.

In winter, advection of Atlantic air masses was the most frequent aerosol transport scenario recognized by Salvador et al. (2010) for European high altitude sites. Quite different results were obtained for high level wet atmospheric deposition in central Europe in summer (Dayan and Lamb 2005). Analysis of global and synoptic scale weather patterns proved, that the most heavily loaded sulphate deposition occurs at the intensified meridional flow over the central Europe, indicating advection of cooler air from northern Europe and North Sea.

- In the analyzed period of two years, three cases of extremely polluted samples were recorded in the winter of 2008, another three in spring (April 2007 and May 2008) and only one in summer (June 2008). Among the analyzed synoptic situations preceding sampling times, those from the warmer half of the year (May to October) were characteristic for more stable atmosphere (high pressure scenario without fronts or low pressure areas over Poland) than those from the colder period (quick movement of fronts). Identified in summer low and moderate moving flows, enhance the vertical air mass exchange with more efficient mixing and upward transport. Such conditions increase the concentration of pollutants in high altitude sites (Salvador et al. 2010). Dyan and Lamb (2005) suggested that in summer the highest concentrations of sulphate in precipitation in central Europe occur when the north-eastern flank of Azores High extends over the British Isles and north-western Europe and blocks the eastward passage of the western cyclones. 
- The trajectory of air flows in the analyzed cases, as well as the composition of samples may indicate a certain role of pollutants discharged locally from low sources located in the vicinity of the sampling site (household burners as emitters of nitrogen and sulphur compounds), particularly in the warmer period characteristic for less intensive air transport. Research carried out for various types of pollutants in north eastern Spain indicates diverse advection directions for various kinds of pollution (Avila and Alarcon 1999). Acid rains in a rural site in north-eastern Spain were associated with precipitation of Atlantic origin. Further investigations concerning relationships between concentration of selected chemicals and synoptic scale weather conditions may help to identify the source areas of particular kinds of pollutants for the investigated site.

Acknowledgements The research was financed from the research grant, contract number N 304021 237, of the Ministry of Science and Higher Education.

Open Access This article is distributed under the terms of the Creative Commons Attribution Noncommercial License which permits any noncommercial use, distribution, and reproduction in any medium, provided the original author(s) and source are credited.

\section{References}

Astel, A., Walna, B., Simeonov, V., Kurzyca, I.: Multivariate statistics as means of tracking atmospheric pollution trends in western Poland. J. Environ. Sci. Health, Part A 43, 313-328 (2008)

Avila, A., Alarcon, M.: Relationship between precipitation chemistry and meteorological situations at a rural site in NE Spain. Atmos. Environ. 33, 1663-1677 (1999)

Birkeland, K.W., Mock, C.J.: Atmospheric circulation patterns associated with heavy snowfall events, Bridger Bowl, Montana, U.S.A. Mt Res Dev 16, 281-286 (1996)

Daily Meteorological Bulletin. Institute of Meteorology and Water Management, Warszawa (2007, 2008)

Dayan, U., Lamb, D.: Global and synoptic-scale weather patterns controlling wet atmospheric deposition over central Europe. Atmos Environ 39, 521-533 (2005)

Dayan, U., Lamb, D.: Influences of atmospheric circulation on the variability of wet sulfate deposition. Int. J. Climatol. (2007). doi:10.1002/joc.1648

EMEP/MSC-W (2007-2009) Transboundary acidifying air pollution in Europe. Oslo: Norwegian Meteorological Institute, from http://tarantula.nilu.no/projects/ccc/emepdata.html

Environment Protection 2005, Central Statistical Office, Warszawa (2005)

Environment Protection 2009, Central Statistical Office, Warszawa (2009)

Gasic, B., MacLeod, M., Scheringer, M., Hungerbuhler, K.: Assessing the impact of weather events at midlatitudes on the atmospheric transport of chemical pollutants using a 2-dimentional multimedia meteorological model. Atmos. Environ. 44, 4489-4496 (2010)

Górski, J., Przybyłek, J.: The problems of anthropogenic threat and protection of ground water at the Wielkopolski National Park area and surrounding, vol. 10, pp. 59-72. Publications of the Wielkopolski National Park, Morena (2003) (In Polish)

Holloway, T., Fiore, A., Hastings, M.G.: Intercontinental transport of air pollution: will emerging science lead to a new hemispheric treaty? Environ Sci Technol. 37, 4535-4542 (2003)

International Co-operative Programme on Assessment and Monitoring of Air Pollution Effects on Forests, United Nations Economic Commission for Europe; Convention on Long-Range Transboundary Air Pollution: "Manual on methods and criteria for harmonized sampling, assessment, monitoring and analysis of the effects of air pollution on forests, Part VI: Sampling and Analysis of Deposition"; Manual (2006)

IPCC: Climate Change 2001. The Scientific Basis. Contribution of the Working Group I of the Third Assessment Report of the Intergovernmental Panel on Climate Change. Cambridge University Press, Cambridge, United Kingdom and New York (2001)

ISO 7888: Water quality-Determination of electrical conductivity. (1985)

ISO 14911: Water quality-Determination of dissolved $\mathrm{Li}^{+}, \mathrm{Na}^{+}, \mathrm{NH}_{4}^{+}, \mathrm{K}^{+}, \mathrm{Mn}^{2+}, \mathrm{Ca}^{2+}, \mathrm{Mg}^{2+}, \mathrm{Sr}^{2+}$ and $\mathrm{Ba}^{2+}$ using ion chromatography-Method for water and waste water. (1998) 
ISO 21438-1: Workplace atmospheres — Determination of inorganic acids by ion chromatography - Part 1: Non-volatile acids (sulfuric acid and phosphoric acid). (2007)

ISO 10523: Water quality-Determination of pH. (2008)

ISO 21438-2: Workplace atmospheres - Determination of inorganic acids by ion chromatography-Part 2: Volatile acids, except hydrofluoric acid (hydrochloric acid, hydrobromic acid and nitric acid). (2009)

ISO 21438-3: Workplace atmospheres_-Determination of inorganic acids by ion chromatography-Part 3: Hydrofluoric acid and particulate fluorides. (2010)

Kalnay, E., Kanamitsu, M., Kistler, R., Collins, W., Deaven, D., Gandin, L., Iredell, M., Saha, S., White, G., Woollen, J., Zhu, Y., Leetmaa, A., Reynolds, R. Chelliah, M., Ebisuzaki, W., Higgins, W., Janowiak, J., Mo, K.C., Ropelewski, C., Wang, J., Jenne, R., Joseph, D.: The NMC/NCAR 40-Year Reanalysis Project. Bull. (1996)

Kolendowicz, L., Busiakiewicz, A., Czernecki, B.: Climatic conditions and features of the air in the Poznań agglomeration. In: Mizgajski, A. (ed.) Natural resources and their protection in the Poznań agglomeration, pp. 42-58. Bogucki Publishing House, Poznań (2010). In Polish

Kowalski, Z.: Protection of the Wielkopolski National Park territory, vol. 11, pp. 7-15. Publications of the Wielkopolski National Park, Morena (2004). In Polish

Kurzyca, I., Walna, B., Siepak, J.: Reliability and comparability - crucial aspects of research on atmospheric precipitation. J. Environ. Anal. Chem. 89, 901-916 (2009)

Matson, P., Lohse, K.A., Hall, S.J.: The globalization of nitrogen deposition: consequences for terrestrial ecosystems. Ambio 31, 113-119 (2002)

Michałowski, J., Raszka, B., Kasprzak, K.: Spatial management of the Wielkopolski National Park, vol. 10, pp. 29-45. Publications of the Wielkopolski National Park, Morena (2003)

Raszka, B.: Spatial distribution of air pollution in the Wielkopolski National Park in the light of the Forest Research Institute technical monitoring in the years 1986-1994, vol. 5, pp. 93-105. Publications of the Wielkopolski National Park, Morena (1997). In Polish

Rodhe, H., Langner, J., Gallardo, L., Kjelstom, E.: Global scale transport of acidifying pollutants. Water, Air, Soil Pollut 85, 37-50 (1995)

Salvador, P., Artinano, B., Pio, C., Afonso, J., Legrand, M., Puxbaum, H., Hammer, S.: Evaluation of aerosol sources at European high altitude background sites with trajectory statistical methods. Atmos. Environ. 44, 2316-2329 (2010)

Scheringer, M.: Long-range transport of organic chemicals in the environment. Environ. Toxicol. Chem. 28, 677-690 (2009)

Tamulewicz, J., Walna, B., Kurzyca, I.: pH and electrical conductivity of atmospheric precipitation versus atmospheric circulations (Ecological Station of A. Mickiewicz University, 1992-2003). In: Kostrzewski, A., Kaczmarek, L., Walna, B. (eds.) State and transformations of the natural environment of the Wielkopolski National Park, pp. 121-124. UAM Publishing House, Poznań (2004) (In Polish)

Twarowski, R., Błachuta, J., Sienkiewicz, R., Gendolla, T., Karska, L., Zawiślak, T., Liana, E., Dąbrowski, A., Wyrodek, S., Kaczmarski, S., Wostek, K.: Monitoring of wet deposition 2000-2001. Manuscript of Institute of Meteorology and Water Management, Wrocław (2001) (In Polish)

Ustrnul, Z., Czekierda, D.: Atlas of extreme meteorological phenomana and synoptic situations in Poland. Institute of Meteorology and Water Management, Warszawa (2009)

Walna, B., Kurzyca, I.: Changes and trends in the chemistry of precipitation in the Wielkopolski National Park (Poland). In: Polisciano, G., Farina, O. (eds.) National Parks: Vegetation, Wildlife and Threats, pp. 51-82. Nova Science Publishers Inc. (2010)

Walna, B., Siepak, J.: Research on the variability of physical-chemical parameters characterizing acidic atmospheric precipitation at the Jeziory Ecological Station in the Wielkopolski National Park (Poland). Sci. Total Environ. 239, 173-187 (1999)

Walna, B., Kurzyca, I., Siepak, J.: Local effects of pollution on chemical composition of precipitation in areas differing in human impact. Pol. J. Environ. Stud. 13, 36-42 (2004)

Walna, B., Kurzyca, I., Siepak, J.: Variations in the fluoride level in precipitation in a human impact region. Water, Air, Soil Pollut 7, 33-40 (2007) 